\title{
PENINGKATAN KEMAMPUAN GURU DALAM PEMBELAJARAN MATEMATIKA SEKOLAH DASAR MELALUI INDUKTIVISASI
}

\author{
Sandra Bayu Kurniawan, Anesa Surya, Siti Istiyati, Sularmi dan Hadiyah \\ Universitas Sebelas Maret (UNS) Surakarta Jawa Tengah, Indonesia \\ Email: sandrabayukurniawan@gmail.com, anesasurya@staff.uns.ac.id, \\ siti_ipgsd@yahoo.co.id, sularmi@staff.uns.qac.id dan hadiyah@staff.uns.ac.id
}

\begin{abstract}
The purpose of this research is to formulate a learning development model and compile elementary school mathematics teaching materials (SD) with an inductive approach, for elementary school teachers who have a non-mathematics education undergraduate background. This type of research is a mixed qualitative and quantitative research and development type. Data collection techniques using: tests and questionnaires. The research subjects were 30 elementary school teachers from Imogiri sub-district, Piyungan district, and Jetis sub-district in Bantul district, Yogyakarta. The data analysis technique used the effectiveness test. The results showed that the learning model with an inductive approach to elementary mathematics was based on a combination of mastery and understanding between Bruner and Piaget's learning theory, selecting and analyzing prerequisite mathematics material, and analyzing the structured form of mathematical material to be studied. The teaching materials prepared by the teacher are based on Bruner's learning theory, namely the enactive, iconic, and symbolic stages. The conclusion of this study is that learning with an inductive approach has increased the effectiveness of learning by obtaining an N-Gian effectiveness score of 1.21 in the high category.
\end{abstract}

Keywords: teacher ability; mathematics learning; induktivisasi

\section{Abstrak}

Tujuan penelitian ini adalah merumuskan model pengembangan pembelajaran dan menyusun bahan ajar matematika Sekolah Dasar (SD) dengan pendekatan induktif, untuk guru SD yang memiliki latar pendidikan sarjana non-pendidikan matematika. Jenis penelitian adalah mixed kualitatif dan kuantitatif dengan jenis research and development. Teknik pengumpulan data dengan menggunakan: tes dan angket. Subjek penelitian adalah 30 guru SD dari kecamatan Imogiri, kecamatan Piyungan, dan kecamatan Jetis di kabupaten Bantul Yogyakarta. Teknik analisis data dengan uji keefektifan. Hasil penelitian menunjukkan bahwa model pembelajaran dengan pendekatan induktif pada matematika SD didasarkan pada kombinasi penguasaan dan pemahaman antara teori belajar Bruner dan Piaget, pemilihan dan menganalisis materi matematika prasyarat, serta menganalisis bentuk terstruktur materi matematika yang akan dipelajari. Bahan ajar disusun guru didasarkan pada teori belajar Bruner, yakni tahapan enactif, iconic, dan symbolic. Kesimpulan penelitian

\begin{tabular}{ll}
\hline How to cite: & Kurniawan, Sandra Bayu., Anesa Surya, Siti Istiyati, Sularmi dan Hadiyah (2021) Peningkatan \\
& Kemampuan Guru dalam Pembelajaran Matematika Sekolah Dasar Melalui Induktivisasi. Syntax \\
& Literate. 6(5). http://dx.doi.org/ 10.36418/syntax-literate.v6i5.2744 \\
E-ISSN: & $2548-1398$ \\
Published by: & Ridwan Institute
\end{tabular}


ini adalah pembelajaran dengan pendekatan induktif telah meningkatkan efektivitas pembelajaran dengan perolehan skor efektivitas N-Gian 1.21 berkategori tinggi.

Kata Kunci: kemampuan guru; pembelajaran matematika; induktivisasi

\section{Pendahuluan}

Pengertian matematika sebagai bahasa simbol (bersifat abstrak) masih bertahan pada mindset guru sekolah dasar (SD), terutama guru yang berlatar belakang pendidikan bukan dari matematika. Hal ini berpengaruh pada pembelajarannya, dimana metode yang dipergunakan adalah transfer konten matematika kepada peserta didik dan bersifat mekanik. Kondisi ini nampak dari sarana buku ajarnya. Untuk bisa memahami simbol matematika tersebut, guru cenderung memanfaatkan buku teks yang ada di sekolah dan lembar kerja peserta didik (LKPD) dalam kegiatan pengajaran sehari-hari. Bila diperhatikan dengan seksama, buku ajar yang digunakan guru cenderung masuk pada tahapan semi abstrak. Hal ini nampak dari pola-pola gambar yang disajikan dengan berbagai variasi bentuk gambar, yang dilanjutkan dengan latihan soal seintensif mungkin. Dalam tahapan teori belajar, tahapan semi abstrak pada hakikinya adalah tahapan untuk meningkatkan pemahaman konsep, bukan membangun konsep matematika.

Memperhatikan tahapan teori belajar dari bruner, kegiatan teaching yang dilakukan guru pada saat ini, diduga telah menghilangkan tahapan konkrit dan semi kongkrit. Hal ini bisa diduga juga, guru belum menguasai aplikasi atau implikasi tahapan pembelajaran dari teori belajar Bruner dan belum memahami hubungan polapola dalam matematika sekolah. Menurut teori belajar Bruner, tahapan yang dihilangkan adalah pada tahapan enaktif. Pengertian tahapan ini, dipahami sebagai tahapan untuk membangun pengetahuan berdasarkan potensi yang dimiliki peserta didik sesuai dengan perkembangannya. Pada tahapan enaktif, konsep matematika dibangun berdasarkan kegiatan pengamatan secara terperinci yang bertujuan untuk membangun pengertian (menggeneralisasikan) atau definisi non-formal menurut logika peserta didik, dan akhirnya membangun teori atau konsep. Tahapan tersebut sering disebut dengan membangun pengetahuan matematika berdasarkan pengalaman empiris peserta didik. Adanya perjanjian tidak formal bersama antara guru dan peserta didik dalam kegiatan pembelajaran, mengkeksplor bahan-bahan pendukung kegiatan pembelajaran menurut urutan yang sesuai dengan logika peserta didik sebagai tahapan pembentukan hubungan pola-pola matematika, menggeneralisasikan dan membangun konsep matematika berdasarkan pengalaman empiris, merupakan tahapan kegiatan pembelajaran matematika yang melibatkan domain ketrampilan, afektif, dan kognitif peserta didik. Tahapan tersebut sebagai bentuk pembelajaran dengan pendekatan induktif.

Pembelajaran dengan pendekatan induktif sejalan dengan amanah kurikulum 2013, dimana pembelajaran yang dilaksanakan merujuk pada pendekatan saintifik. Mengeksplorasi fakta-fakta konkrit, menggeneralisasi secara empiris, dan membangun teori atau konsep matematika merupakan alur pendekatan saintifik yang bersifat induktif. Pendekatan saintifik tersebut cenderung memberikan waktu kepada guru untuk 
melakukan pengamatan secara terperinci, sehingga menekankan pada pengembangan secara berimbang pada domain keterampilan, afektif, dan kognitif. Konsep pembelajaran dengan pendekatan induktif inilah yang diduga tidak dipahami dan dimengerti oleh guru yang memiliki latar belakang pendidikan sarjana bukan dari matematika. Hasil observasi pra-penelitian menyebutkan bahwa indikator belum dipahami dan dimengerti pembelajaran dengan pendekatan induktif adalah: 1) tiap kompetensi matematika dipandang sebagai bentuk kompetensi yang bersifat parsial, tidak ada hubungan tiap-tiap kompetensi (Pola matematika). 2) Mengidentifikasi tiap obyek dengan penyebutan yang sama. 3) sistematika dari struktur matematika sering kali tumpang tindih. Ketiga indikator tersebut perlu diaalisis dan diteliti agar kompetensi guru yang berlatar belakang bukan dari matematika dapat mewujudkan bentuk pembelajaran tahapan kongkrit dan semi kongkrit.

Kegiatan pembelajaran matematika dengan pendekatan induktif dalam penelitian ini perlu dirumuskan dalam bentuk desain model pembelajarannya. Model tersebut selain bersifat pembelajaran yang mengimbangkan perkembangan domain keterampilan, afektif, dan kognitif, juga efektif dalam peningkatan kompetensi guru SD dalam penguasaan konten matematika. Model pembelajaran dengan pendekatan induktif, kegiatan dalam membangun konsep matematika, sejalan dengan teori Piaget. Adapun ciri peserta didik di SD, yakni: cara berpikir operasionalnya pada tahap kongkret dan pada ranah sosialnya, peserta didik suka berkelompok. Kondisi inilah yang mendorong pentingnya penelitian untuk membangun model pembelajaran matematika dengan pendekatan induktif melalui kegiatan-kegiatan produktif, sehingga mampu untuk meningkatkan kompetensi pengetahuan guru yang berlatar belakang bukan matematika.

Penelitian membangun model pembelajaran dengan pendekatan induktif direncanakan di sekolah dasar se-kecamatan Imogiri, Piyungan, dan Jetis, Kabupaten Bantul. Hal ini dikarenakan, beberapa sekolah tersebut memiliki guru dengan latar belakang bukan sarjana dari matematika. Banyaknya guru tersebut secara metodologi dapat memenuhi penetapan sampel bila dengan pendekatan kuantitatif. Hasil observasi juga ditemukan bahwa guru-guru memiliki motivasi yang kuat untuk melayani peserta didik dan memiliki keinginan kuat untuk belajar tentang matematika, serta adanya potensi yang besar dari sisi kepercayaan masyarakat untuk menyekolahkan anakanaknya di sekolah tersebut. Hal ini merupakan sumber data riset yang baik untuk diteliti. Kondisi tersebut yang memotivasi tim penelitian untuk merumuskan model pembelajaran matematika dengan pendekatan induktif agar dapat mengoptimalkan kompetensi guru SD.

Pendekatan Induktif pada awalnya bersifat mempercayai begitu saja berdasarkan apa yang dilihat, dirasa, dan dimanipulasi, tetapi belum masuk tahapan menggunakan rasional. Berpikir induktif dalam prosesnya berlangsung dari khusus ke yang umum. Tokoh pendekatan induktif adalah filosof Prancis Bacon dari Inggris. (Evans \& Swan, 2014) yang menyatakan bahwa: "Inductive approach, also known in inductive reasoning, starts with the observations and theories are proposed towards the end of the research process as a result of observations". Pernyataan tersebut memberi pemahaman bahwa 
pendekatan induktif sama halnya dengan penalaran induktif, sehingga pada tahapan awal dimulai dengan pengamatan dan teori atau konsep mata pelajaran diberikan pada akhir. Sistematika ini mengisyaratkan bahwa untuk membangun pengetahuan yang bersifat umum, tahapan membangun pengetahuan didasarkan oleh pengamatan serta pencermatan fakta-fakta konkrit yang banyak diperoleh oleh responden, sebagai dasar pembentukan pengetahuan dan bersifat empiris. (Saunders, Lewis, \& Thornhill, 2009) menyatakan bahwa: "Inductive reasoning is based on learning from experience. Patterns, resemblances and regularities in experience (premises) are observed in order to reach conclusions (or to generate theory)". Pernyataan tersebut memberi masukan bahwa penalaran induktif itu belajar dari pengalaman (premis). Memahami pola-pola, kemiripan, dan keteraturan dalam pengalaman yang pada akhirnya membangun kesimpulan atau menghasilkan teori. Hal ini sejalan dengan pendapat (Trianto, 2010) yang menyatakan bahwa: "berpikir Induktif merupakan cara berpikir yang digunakan apabila seseorang membuat kesimpulan berdasarkan informasi atau fakta yang dimiliki dan berdasarkan prinsip-prinsip penemuan, serta dibuat dari yang spesifik ke yang umum".

Pembelajaran dengan pendekatan induktif memiliki tahapan yang sama dengan penelitian induktif, yakni bersifat sistematik dan menyesuaikan dengan tahapan teori belajar. (Bernard, 2017) menyatakan bahwa: "Inductive research "involves the search for pattern from observation and the development of explanations - theories - for those patterns through series of hypotheses". Pernyataan tersebut memberikan pemahaman bahwa penelitian induktif dalam pengamatan berusaha untuk mencari pola-pola yang kemudian memberikan penjelasan hubungan antar pola melalui teori berdasarkan hipotesis. Hal ini dipertegas (Wena, 2009) yang menyatakan bahwa: "pengolahan pesan secara induktif bermula dari (i) fakta atau peristiwa khusus, (ii) penyusunan konsep berdasarkan fakta-fakta, (iii) penyusunan generalisasi berdasarkan konsep-konsep". Selanjutnya, pengolahan pesan dalam pendekatan induktif dikemukakan oleh (Wena, 2009) sebagai berikut :

1. Memilih konsep, prinsip, aturan yang akan disajikan dengan pendekatan induktif.

2. Menyajikan contoh-contoh khusus konsep, prinsip atau aturan itu yang memungkinkan siswa memperkirakan (hipotesis) sifat umum yang terkandung dalam contoh-contoh itu.

3. Disajikan bukti-bukti yang berupa contoh tambahan untuk menunjang atau menyangkal perkiraan itu.

4. Disusun pertanyaan mengenai sifat umum yang telah terbukti berdasarkan langkah-langkah terdahulu.

Berdasarkan pengertian di atas, dapat didefinisikan bahwa pendekatan induktif adalah proses membangun pengetahuan yang diawali dengan pemilihan konsep atau prinsip yang disajikan dalam bentuk khusus dan secara sistematika dibimbing membangun konsep atau prinsip yang bersifat umum.

Dalam Kamus Besar Bahasa Indonesia kata kemampuan berasal dari kata mampu, yang berarti kuasa. Dengan tambahan awalan ke dan akhiran an, kata mampu menjadi 
kemampuan yang berarti kecakapan. Kemampuan dalam bahasa Inggris menjadi competence. Dalam penelitian ini, kata kompetensi dihubungkan dengan kompetensi guru. (Weinstein, 1986) menyatakan bahwa: "Competency is underlying characteristic of an individual that is causally related to criterion-referenced effective and/or superior performance in a job or situation". Pernyataan tersebut memberikan pemahaman bahwa kompetensi adalah karakteristik dasar yang dimiliki seseorang dan berkaitan dengan kinerja berkriteria efektif serta unggul dalam suatu pekerjaan atau situasi tertentu. Dari pernyataan tersebut, bagian yang menjadi fokus kompetensi adalah pada kata underlying characteristic. Hal ini dikarenakan, karakteristik itu merupakan bagian yang terpenting dan melekat pada kepribadian seseorang dan dapat memprediksi berbagai situasi dan jenis pekerjaan. Fokus yang kedua adalah causally related. Hal tersebut dikarenakan kompetensi dapat menyebabkan atau memprediksi perilaku dan kinerja. Selanjutnya, fokus yang ketiga adalah criterion-referenced. Hal ini dikarenakan melalui kompetensi dapat diprediksi siapa-siapa saja yang kinerjanya baik atau buruk, berdasarkan kriteria atau standar tertentu.

Untuk selanjutnya, (Weinstein, 1986) juga menyatakan bahwa: "A competency is composed of skill, knowledge, and attitude, but in particular the consistent applications of those skill, knowledge, and attitude to the standard of performance required in employment". Pernyataan tersebut memberi masukan bahwa pada dasarnya kompetensi tidak hanya mengandung pengetahuan, keterampilan dan sikap, namun yang lebih urgen adalah bagaimana menerapkan pengetahuan, keterampilan, dan sikap dalam pekerjaan (menjadi guru). Hal ini juga diperkuat oleh (Usman, 2006) yang menyatakan bahwa: "kompetensi merupakan kemampuan dan kewenangan guru dalam melaksanakan profesi keguruannya Guru". Selanjutnya, (Baharudin, 2012) menyatakan bahwa: "kompetensi adalah seperangkat tindakan intelegen penuh tanggung jawab yang harus dimiliki seseorang sebagai isyarat untuk dianggap mampu melaksanakan tugas-tugas dalam bidang tertentu. Sifat intelegensi harus ditunjukkan sebagai kemahiran ketetapan, dan keberhasilan bertindak". Berdasarkan pengertian di atas, dapat ditarik pemahaman bahwa kompetensi guru adalah kecakapan guru dalam melaksanakan kegiatan yang didasari oleh intelegensinya untuk menata dan menyampaikan pesan materi pelajaran dengan tepat, efektif, dan berhasil.

Pembelajaran sebagai peralihan dari pengajaran dipandang sebagai bentuk indikasi bahwa pembelajaran saat ini mengikuti aliran psikologi. Secara hakiki, kegiatan pengajaran cenderung memposisikan peserta didik sebagai obyek. Sedangkan pada pembelajaran, peserta didik diposisikan sebagai subyek. Kata pembelajaran berasal dari kata belajar, sehingga perlu adanya pengertian tentang apa itu belajar. (Chueachot. S. Srisa-ard. B., \& Srihamongkol, 2013) menyatakan bahwa: "learning is the process by witch can activity orginates or is changed through training prosedure (wheter in the laboratory or in natural environment) as distringuished from changes by factor not atributtable to training”. Pernyataan tersebut memberi pemahanan bahwa belajar adalah suatu proses yang sebelum dan sesudah melakukan aktivitas akan dapat diperhatikan perubahannya yang disebabkan bukan aktivitas tersebut. (Johnson, 2002) menyatakan 
bahwa: "learning is shown by change in behavior as a result of experince". Pernyataan tersebut memberi pemahaman bahwa belajar memberikan perubahan tingkah laku dari hasil pengalaman. Berdasarkan pengertian tersebut, dapat dimengerti bahwa melalui belajar akan mengembangkan perubahan tingkah laku karena adanya penguasaan ilmu pengetahuan dan sikap sebagai pembentukan pengalaman yang secara sengaja.

Memperhatikan pengertian belajar, perlu adanya penegasan tentang pengertian pembelajaran. Dalam kegiatan penelitian mandiri aktif pengertian pembelajaran merujuk dari (Johnson, 2002) yang menyatakan bahwa: "a relatively permanent change in response potentiality which occurs as a result of reinforced practice" dan "a change in human disposition or capability. Which can be retained, and which is not simply ascrible to the process of growth". Pernyataan tersebut memberikan tiga prinsip, yaitu belajar menghasilkan perubahan tingkah laku yang bersifat permanen, peserta didik memiliki potensi yang merupakan benih kodrati yang harus ditumbuhkembangkan, dan pencapaian kualitas ideal tidak tumbuh alami linear sejalan dengan kehidupan. Melalui pengertian belajar dan pembelajar di atas, perlu dideskripsikan perubahan-perubahan hasil belajar dan pembelajaran.

Peserta didik agar mau untuk belajar, guru sebagai responden dalam penelitian ini, perlu memperhatikan tingkat perkembangan intelektualnya. Dalam penelitian mandiri ini, teori belajar yang menjadi rujukan untuk diperhatikan adalah perkembangan intelektual peserta didik dari Piaget. (Wena, 2009) menyatakan bahwa: "tahapan perkembangan intelektual anak berusia 7 sampai 12 tahun adalah pada tahapan praoperasional konkrit, yang dicirikan: perkembangan pemikiran yang dijalankan secara terbalik, operasi-operasi logis, konservasi, mampu memecahkan masalah konkrit, dan pemikirannya berbasis pengalaman”. Selanjutnya, untuk memperkuat pelaksanaan penelitian mandiri juga dirujuk teori belajar Bruner. Teori ini dideskripsikan oleh (Chueachot. S. Srisa-ard. B., \& Srihamongkol, 2013) yang menyatakan bahwa: "perkembangan pemikiran siswa melalui konsep mode representasi (modes of representation) yang urutannya sudah tetap, yaitu: enactive mode of representation, iconic mode of representation, and symbolic mode of representation". Aplikasi dari teori belajar Bruner dalam teori pembelajaran adalah pembelajaran yang dilaksanakan guru agar peserta didik mau untuk belajar, perlu ada tahapan-tahapannya, yaitu: tahapan konkrit, semi konkrit dan semi abstrak, serta abstrak.

Istilah matematika berasal dari kata Yunani "mathein" atau "mathenein", yang artinya "mempelajari". Untuk mempelajari dan pada akhirnya bisa memahami perlu tahapan-tahapan secara sitematis dengan memperhatikan tingkat perkembangan peserta didik. Tahapan untuk melihat tingkat pemahaman mempelajari matematika dikemukakan oleh In Woo, Lew, Park, \& Seo (Siregar, 2018) yang menyatakan bahwa: "The mathematics is understood if its mental representation is part of a network of representations. The degree of understanding is determined by the number and strength of its connections. A mathematical idea, procedure, or fact is understood thoroughly if it is linked to existing networks with stronger or more numerous connections". Pernyataan tersebut memberikan masukan bahwa matematika dapat dipahami apabila representasi 
mentalnya adalah bagian dari jaringan representasi. Tingkat pemahaman ditentukan oleh banyak dan kekuatan koneksinya. Gagasan, prosedur, atau fakta matematika dipahami secara menyeluruh jika benar terhubung ke jaringan yang ada koneksinya. Hal ini juga dipertegas oleh (Wena, 2009) yang menjelaskan pengertian matematika sebagai berikut:

a. Matematika adalah cabang ilmu pengetahuan eksak dan terorganisir secara sistematik.

b. Matematika adalah pengetahuan tentang bilangan dan kalkulasi.

c. Matematika adalah pengetahuan tentang penalaran logis dan berhubungan dengan bilangan.

d. Matematika adalah pengetahuan tentang struktur-struktur logis yang terorganisasikan.

e. Matematika adalah pengetahuan tentang aturan-aturan yang ketat.

Pemahaman tentang matematika dalam penelitian ini perlu dipertegas dengan mempertimbangkan peningkatan pemahaman terhadap matematika dari guru-guru SD yang bukan dari matematika. In Woo, Lew, Park, \& Seo (Siregar, 2018) menyatakan bahwa:

In light of these points, we can consider different ways in which we can assess this understanding. Possible methods suggested by Hiebert and Carpenter (1992) were to analyse:

- Students' errors.

- Connections made between symbols and symbolic procedures and corresponding referents.

- Connections between symbolic procedures and informal problem solving situations.

- Connections made between different symbol systems.

pernyataan tersebut menandaskan bahwa metode untuk dapat meningkatkan pemahaman matematika, hal-hal yang perlu dianalisa adalah: tingkat kesalahan siswa (dalam hal ini guru), bagaimana membuat hubungan antara simbol dan prosedur serta ketersedian referensi yang sesuai, menghubungkan prosedur simbolik dengan penyelesaian masalah informal, serta menghubungkan antara antar sistem simbol. Pernyatan tersebut juga ditegaskan oleh Ruseffendi (Wena, 2009) yang menyatakan bahwa: "matematika adalah ilmu keteraturan, ilmu tentang struktur yang terorganisasikan mulai dari unsur yang tidak didefinisikan, ke unsur yang didefinisikan ke aksioma atau postulat dan akhirnya ke dalil". Berdasarkan pengertian di atas, pembelajaran matematika dapat didefinisikan sebagai proses kegiatan untuk mengerti dan memahami struktur-struktur logis matematika yang terorganisasi melalui tahapantahapan yang jelas (memiliki struktur dan hubungan), yakni konkret, semi, dan abstrak. Untuk hal tersebut, dalam penelitian ini perlu ditandaskan bahwa pembelajaran matematika yang dilaksanakan oleh guru perlu adanya tahapan yang akan ditunjukkan hubungan antar kompetensi atau kompetensi tiap konten matematika yang bersifat integrit. 
Beberapa penelitian induktif yang pernah dilaksanakan, yaitu:

1. Penelitian oleh Mariam Ar Rahmah, judul: Pendekatan induktif untuk meningkatkan kemampuan pemahaman matematis pada siswa SMP, Biormatika, 2018, Vol.4 No.1, fokus penelitian pada kemampuan pemahaman.

2. Penelitian olen Ani Aisyah, judul: Studi literatur: Pendekatan induktif untuk meningkatkan kemampuan generalisasi dan selfconfident siswa SMK, JP3M, 2016, Vol. 2 No. 1, fokus penelitian pada peningkatan pemahaman dan generalisasinya.

Penelitian tersebut berfokus pada peningkatan pemahaman terhadap konten matematika melalui latihan soal yang bersifat non-formal dan bersifat parsial. Persamaan dalam penelitian ini adalah pada bagaimana meningkatkan pemahaman pada konten matematika. Sedangkan perbedaannya, penelitian ini berfokus pada proses induktivisasi untuk tiap-tiap tahapan Bruner, yakni: tahapan konkret, semi konkret, dan semi abstrak. Berdasarkan tahapan tersebut, guru diharapkan mampu membangun struktur konten matematika yang integred dan diujudkan dalam bahan ajar, seperti buku kegiatan siswa.

\section{Metode Penelitian}

Tempat penelitian ini akan dilaksanakan di sekolah dasar se-kecamatan Imogiri, Piyungan, dan kecamatan Jetis kabupaten Bantiul Daerah Istimewa Yogyakarta. Pertimbangan dalam pemilihan tempat yaitu: a) Peneliti memiliki kemudahan akses untuk melakukan penelitian di sekolah tersebut; b) belum pernah dilakukan penelitian sejenis. Penelitian dilakukan selama 7 bulan, dimulai pada Bulan Mei sampai dengan November tahun 2020 melalui tahap persiapan, pelaksanaan, dan penyelesaian penelitian.

Dari permasalahan yang ada, maka peneliti menggunakan metode penelitian kuantitatif pre-experimental, dimana desain percobaannya tidak mencakupi semua syarat dari suatu desain percobaan sebenarnya. Kemudian dari beberapa desain preexperimental, peneliti memilih menggunakan desain one group pretest-posttest, yaitu perlakukan dikenakan pada satu kelompok unit percobaan tetentu, kemudian diadakan penggukuran terhadap variabel dependen. Dalam percobaan ini hanya menggunakan satu kelompok unit percobaan tanpa adanya kontrol.

\begin{tabular}{|ccc|}
\hline $\mathrm{O}_{1}$ & $\mathrm{X}$ & $\mathrm{O}_{2}$ \\
Pre-test & Treatment & Post-Test \\
\hline
\end{tabular}

Populasi ialah suatu objek atau subjek yang menyandang kualitas dan karakateristik tertentu dalam suatu wilayah yang digeneralisasikan yang telah ditentukan oleh peneliti untuk dipelajari, dihitung, dan diukur baik kualitatif maupun kuantitatif yang kemudian diambil simpulannya, (Mundir, 2013). Populasi yang telah ditetapkan adalah guru sekolah dasar se-kecamatan Imogiri, piyungan dan Jetis kabupaten Bantul Daerah Istimewa Yogyakarta, yang memiliki latar belakang sarjana non Pendidikan matematika atau Pendidikan guru sekolah dasar (PGSD). 
Sampel berarti contoh, bagian dari karakteristik populasi. Kesimpulan dari contoh pasti akan sama dengan populasi yang menjadi sumber sampel, karena keduanya memiliki karakteristik yang sama (Sugiyono, 2018). Sampel yang akan digunakan dalam penelitian ini ialah guru di SD dasar se-kecamatan Imogiri, Piyungan, dan Jetis kabupaten Bantul Daerah Istimewa Yogyakarta, yang memiliki latar belakang sarjana non Pendidikan matematika atau Pendidikan guru sekolah dasar (PGSD).

Teknik pengambilan sampel yang dipilih peneliti ialah probability sampling, dimana teknik probability sampling ialah teknik yang memberi kesempatan yang sama bagi populasi supaya dipilih menjadi anggota sampel. Probability sampling yang digunakan ialah simple random sampling, dimana peneliti memilih anggota sampel secara random tanpa melihat jenjang di dalam populasi juga karena jumlah populasi yang sedikit (Sugiyono, 2018). Adapun langkah pengambilan sampel sebagai berikut:

Menginventarisasi banyaknya guru yang berlatar belakang sarjana non Pendidikan matematika atau Pendidikan guru sekolah dasar (PGSD). Menetapkan tiap kecamatan diambil 10 guru dengan kriteria 5 guru dari kelompok SD yang memiliki paralel kelas lebih dari satu dan 5 guru dari kelompok SD dengan paralel satu kelas.

Teknik pengumpulan data yang akan digunakan dalam penelitian ini yakni teknik tes dan angket kuisioner. Tes adalah suatu alat atau prosedur yang sistematis dan objektif untuk memperoleh data-data atau keterangan-keterangan yang diinginkan tentang seseorang, dengan cara yang boleh dikatakan tepat dan cepat. Tes ini bertujuan untuk mengetahui sejauh mana pengetahuan guru tentang matematika induktif. Bentuk tes yang digunakan ada dua, yaitu berupa pertanyaan terbuka yang berbentuk tes essay dan tes unjuk kerja berupa artikel ilmiah. Sedangkan materi tes mengenai matemtika induktif. Tes dilakukan dua kali, yaitu sebelum dilaksanakannya treatment yang disebut pre test, dan sesudah dilaksanakannya treatiement atau post test (Sugiyono, 2018).

Setelah nilai tes awal dan tes akhir pada kelas diketahui, kemudian dihitung untuk mengetahui rerata antara pre tes dengan post tes. Untuk menguji efektivitas pembelajaran matematika dengan induktif digunakan perhitungan manual yaitu dengan rumus efektivitas N-Gain sebagai berikut.

$$
<\mathrm{g}>=\frac{\text { Nilai posttest }- \text { Nilai pretest }}{\text { Skor idel }- \text { Nilai Pretest }}
$$

Kategori nilai setelelah dihitung dengan N-Gain (Sugiyono, 2017b) dapat dilihat pada Tabel, 2 sebagai berikut:

Tabel 2.

Normalisasi $N$-Gain

\begin{tabular}{ll}
\hline$<\mathrm{g}>$ & Kategori \\
\hline$\geq 0.7$ & Tinggi \\
$0,3<(<\mathrm{g}>)<0,7$ & Sedang \\
$(<\mathrm{g}>)$ & Rendah \\
$<0,3$ & \\
\hline
\end{tabular}




\section{Hasil dan Pembahasan}

Penelitian mandiri aktif dengan judul peningkatan kemampuan guru dalam pembelajaran matematika SD melalui induktifisasi melalui tahapan sebagi berikut:

\section{A. Hasil Penelitian}

\section{Tahapan Tes Awal}

Tes awal dilaksanakan dengan tujuan untuk memperoleh data tentang tingkat penguasaan dasar matematika yang selanjutnya diuraikan menurut kelemahan yang dialami oleh guru. Adapun isi tes adalah: kompetensi teori belajar Bruner dan Piaget, aplikasi tahapan teori belajar Bruner dalam matematika, konsep matematika sebagai materi prasyarat untuk membangun konsep matematika yang akan dipelajari. Kompetensi teori belajar diujikan untuk mengetahui seberapa besar pemahaman guru dalam mensikapi kepahaman konten teori belajar. Aplikasi teori belajar diujikan untuk mengetahui tahapantahapan yang perlu dilakukan guru dalam menyusun perencanaan dan pelaksanaan pembelajaran matematika. Konsep materi matematika prasyarat diujikan untuk mengetahui kepahaman guru bahwa matematika itu bersifat struktural.

Adapun hasil perolehan data dari tes awal dari 30 guru sebagai sampel adalah sebagai berikut: mean tes awal adalah $\bar{x}=55, S_{a}^{2}=129.31$ dan $S_{i}=$ 11.37, hal ini dapat dinyatakan bahwa kategori hasi; tes adalah kurang

\section{Penyusunan Materi Induktif}

Pelaksanaan penelitian setelah tes awal dilanjutkan dengan pelatihan yang berbentuk pembelajaran matematika dengan mendasarkan pada teori belajar Bruner, pemilihan bahan manipulatif atau media, dan merumuskan materi prasyarat untuk membangun konsep baru bagi peserta didik. Adapun sistematika pelatihan adalah sosialisasi tentang teori belajar dan aplikasinya dalam pembelajaran matematika, serta pemilihan dan menguraikan konsep matematika pendukung materi prasyarat. Dalam praktek pelatihan ini peserta dikelompokan menjadi 5. Selanjutnya menyusun perencanaan pembelajaran yang dimulai dengan tahapan enactif, iconic, dan tahapan symbolic.

Hasil penilain ahli materi memperoleh skor 80 berkategori baik sekali. Sedangkan, dari ahli media diperoleh skor 63 berkategori baik sekali.

\section{Tahapan Tes Akhir}

Hasil tes akhir dari materi tes, diperoleh skor mean tes akhir adalah $\bar{x}=$ $79.67 S_{a}^{2}=72.30$ dan $S_{i}=8.50$, hal ini dapat dikatakan berkriteria baik (B). Selanjutnya, perhitungan efektivitas pembelajaran matematika dengan induktif menggunakan perhitungan efektivitas N-Gain:

$$
<\mathrm{g}>=\frac{\text { Nilai posttest }- \text { Nilai pretest }}{\text { Skor idel }- \text { Nilai Pretest }}=\frac{79.67-55}{100-79.67}=1.21
$$

Perolehan skor N-Gain 1.21 masuk dalam kategori Tinggi karena lebih dari 0.7 
Berdasarkan hasil penelitian di atas, maka dapat dikatakan penguasaan matematika induktif tinggi jika, $\geq 0,7$. Sedangkan dikatakan sedangan jika $N$ gain score $0,3<(<\mathrm{g}>)<0,7$. Dikatakan rendak jika $\mathrm{N}$ gain skore $<0,3$.

\section{B. Pembahasan}

Bentuk pengembangan melalui model pembelajaran dengan pendekatan induktif pada matematika SD didasarkan pada kombinasi penguasaan dan pemahaman antara teori belajar Bruner dan Piaget, pemilihan dan menganalisis materi matematika sebagai materi prasyarat, serta menganalisis secara terstruktur materi matematika yang akan dipelajari. Kombinasi penguasaan materi ini selaras dengan yang dijelaskan oleh Evans, yang menyatakan: "Inductive approach, also known in inductive reasoning, starts with the observations and theories are proposed towards the end of the research process as a result of observations". Kombinasi ini memberikan tahapan secara struktur bagaimana aplikasi teori belajar dalam matematika memberi kontribusi pada system pembelajaran matematika. Sistem ini memberikan pemahaman kepada peserta pelatihan untuk Menyusun rencana pembelajaran yang menempatkan materi yang akan dipelajari ditempatkan pada akhir.

Pembelajaran dengan pendekatan induktif selaras dengan penelitian induktif. Didasarkan pada fakta-fakta yang ada di permukaan, disusun pola-pola serta hubungannya, dan selanjutnya merumuskan konsep yang mampu digenarilisasikan. Hal sesuai dengan teori belajar Bruner, dimana penemuan faktafakta sama halnya dengan tahapan enactif, Menyusun pola-pola hubungan adalah tahapan iconic, dan merumuskan kopnsep adalah tahapan simbolik. Kesamaan ini selaras dengan yang dijelaskan oleh Bernard. bahwa : Inductive research "involves the search for pattern from observation and the development of explanations theories-for those patterns through series of hypotheses. Melalui pemahaman inilah nampak adanya perubahan pada peserta pelatihan. Perubahan tersebut dapat dicermati dari peningkatan peroelehan mean tes dan variannya.

Adanya peningkatan nilai rerata tes sebesar 24.67point dan menjadikan varian mengecil 57.01, menandaskan bahwa pembelajaran matematika dengan pendekatan induktif untuk guru dengan berlatar belakang non Pendidikan matematika atau PGSD, telah mengadaptasikan langkah-langkah penelitian dengan pendekatan induktif. Adapun Langkah tersebut, yaitu: adanya fakta atau peristiwa khusus, penyusunan konsep berdasarkan fakta-fakta, dan penyusunan generalisasi berdasarkan konsep-konsep. Fakta atau peristiwa khusus ini sama halnya mengajak peserta didik untuk mau mengeksplore. Penyusunan konsep dalam hal ini, peneliti mengajak peserta untuk membangun pengetahuan berdasarkan logika yang dimiliki atau guru nantinya mampu menyesuaikan perkembangan kognitif peserta didik. Sedangkan, penyusunan generalisasi dalam hal ini mengarahkan peserta untuk mampu beragumentasi secara ilmiah, atas apa yang menjadi penyebab perubahannya. 
Bentuk bahan ajar matematika SD dengan pendekatan induktif mengikuti tahapan belajar dari Bruner dan membebaskan peserta didik dari kelemahan instruksi dengan memberikan kolaborasi antara matematika dengan materi membaca dan menulis. Melalui pelatihan, nampak adanya perubahan peserta dalam menyusun rencana pembelajaran. Tahapan enactif telah dipahami oleh guru dann diwujudkan dalam bentuk membawa benda konkret yang selanjutnya untuk hal ini diwujudkan dalam bentuk foto. Tahapan iconic ditunjukkan dengan lukisan atau gambar benda, dan selanjutnya tanpa bantuan benda. Tahapan ini juga mempengaruhi pada kreativitas guru dalam mengurai materi pelajaran yang dipelajari. Hal ini Nampak dari hasil karya perencanaan pembelajaran.

Hasil karya rencana pembelajaran dari guru yang dinilaikan kepada ahli materi matematika dan ahli media diperoleh data: 80 dari 85 dengan kriteria Baik Sekali serta 63 dari 65 dengan kriteria Baik Sekali menandaskan bahwa kemampuan guru dalam menyusun rencana pembelajaran matematika telah baik (atau mengalami peningkatan). Dalam pelaksanaan pembelajarannya, hasil karya tersebut sangat efekti karena memperoleh skor N-Gain sebesar 1.21 yang masuk dalam kategori Tinggi karena lebih dari 0.7. tingginya skor N-Gain berefek pada peningkatan rerata pada tes akhir dan mengecilnya tingkat variannya.

Memperhatikan deskripsi di atas maka pembelajaran dengan induktivisasi telah meningkatkan kompetensi kemampuan guru dalam menyusun pembelajaran matematika. Mengingat pendekatan pembelajaran induktif itu sama dengan penelitian induktif maka pendekatan ini telah mengarahkan guru memiliki karakter dasar yang spesifik sebagai bentuk kepemilikan kompetensi dalam pembelajaran matematika. Hal ini sejalan dengan yang dijelaskan oleh Weinstein bahwa competency is underlying characteristic of an individual that is causally related to criterion-referenced effective and/or superior performance in a job or situation.

Karakter dasar yang spesifik sebagai wujud dari peningkatan kemampuan dapat diperhatikan dari kreatifnya guru dalam menyusun tahapan pembelajaran matematika. Hal ini menandaskan bahwa pendekatan induktif tidak hanya meningkatkan pengetahuan, keterampilan dan sikap, namun yang lebih urgen kepada bagaimana menerapkan pengetahuan, keterampilan, dan sikap dalam pekerjaan (menjadi guru). Hal ini selaras dengan yang dinyatakan oleh Weinstein bahwa a competency is composed of skill, knowledge, and attitude, but in particular the consistent applications of those skill, knowledge, and attitude to the standard of performance required in employmen.

\section{Kesimpulan}

Model pembelajaran matematika dengan pendekatan induktif untuk guru yang berlatar belakang bukan dari matematika ditekankan pada tiga hal yang perlu dipahami. Penguasaan teori belajar Bruner dan Piaget beserta bagaimana aplikasinya. Realisasi penguasaannya yakni konten matematika perlu dianalisis kemudian disusun manurut apa yang harus ditampilkan serta diajarkan pada tahapan konkret, semi, dan abstrak. 
Sandra Bayu Kurniawan, Anesa, Istiyati, Sularmi dan Hadiyah

Analisis dan penyusunan konten matematika disesuaikan dengan memperhatikan perkembangan siswa SD agar dapat menentukan strategi pembelajarannya. Selanjutnya. Menganalisis materi matematika untuk dikelompokan sebagai materi prasyarat dan materi inti.

Sedangkan, menganalisis hubungan tiap konten matematika. Merupakan tahapan penguasaan yang ketiga. Tujuan tahap ke tiga pembelajaran tersebut yakni untuk memahamkan bahwa matematika merupakan pengetahuan yang bersifat terstruktur dan materinya terintegrasi. Ketiga tahapan pemahaman pembelajaran matematika untuk guru SD yang berlatar belakang bukan dari matematika, berdasarkan hasil penelitian, telah menunjukkan pencapaian yang optimal baik dari peningkatan rerata, mengecilnya skor varian, dan skor efektivitas N-Gian memperoleh 1.21 dengan kategori tinggi. 
Peningkatan Kemampuan Guru dalam Pembelajaran Matematika Sekolah Dasar Melalui Induktivisasi

\section{BIBLIOGRAFI}

Arikunto, Suharsimi. (2010). Prosedur Penelitian (Suatu Pendekatan Praktik). Jakarta: Rineka Cipta. Google Scholar

Baharudin, Wahyuni. (2012). Teori Belajar \& pembelajaran. Yogyakarta: Ar-Ruzz Media. Google Scholar

Bernard, H. Russell. (2017). Research methods in anthropology: Qualitative and quantitative approaches. Rowman \& Littlefield. Google Scholar

Chueachot. S. Srisa-ard. B., \& Srihamongkol, Y. (2013). The Development of an assesment for Leaning Model for Elementary Classroom". Nternational Education Studies, 6(9), 119-124. Google Scholar

Evans, Sheila, \& Swan, Malcolm. (2014). Developing students' strategies for problem solving in mathematics: The role of pre-designed "Sample Student Work." Educational Designer, 2(7). Google Scholar

Johnson, Elaine B. (2002). Contextual teaching and learning: What it is and why it's here to stay. Newbury: Corwin Press. Google Scholar

Prasetyo, B., \& Jannah, L. M. (2017). Metode Penelitian Kuantitatif: Teori dan Aplikasi. Jakarta: PT Rajagrafindo Persada. Google Scholar

Purwanto. (2008). Metode Penelitian Kuantitatif untuk Psikologi dan Pendidikan. Yogyakarta: Pustaka Pelajar. Google Scholar

Saunders, Mark, Lewis, Philip, \& Thornhill, Adrian. (2009). Research methods for business students. Pearson education. Google Scholar

Siregar, Syafaruddin. (2018). Meningkatkan Kemampuan Guru Dalam Menerapkan Pembelajaran Kontekstual Melalui Focus Group Discussion (FGD) DI SMK Negeri 1 Sirandorung Tahun Pelajaran 2017/2018. NUSANTARA: Jurnal Ilmu Pengetahuan Sosial, 5(1), 14-19. Google Scholar

Sugiyono. (2017a). Metode Penelitian Kombinasi (Mixed Methods). Bandung: Alfabeta. Google Scholar

Sugiyono. (2017b). Metode Penelitian Pendidikan. Bandung: Alfabeta. Google Scholar

Trianto, M. Pd. (2010). Mendesain model pembelajaran inovatif-progresif: Konsep, landasan dan implementasinya pada Kurikulum Tingkat Satuan Pendidikan (KTSP). Jakarta: Kencana. Google Scholar

Usman, Moh Uzer. (2006). Menjadi Guru Profesional, Bandung: PT. Remaja Rosdakarya. Google Scholar 
Sandra Bayu Kurniawan, Anesa, Istiyati, Sularmi dan Hadiyah

Weinstein, Claire E. (1986). The teaching of learning strategies. In. Handbook of Research on Teaching (3 Rd Ed.), 315-327. Google Scholar

Wena, Made. (2009). Strategi pembelajaran inovatif kontemporer suatu tinjauan konseptual operasional. Jakarta: Bumi Aksara. Google Scholar

\section{Copyright holder:}

Sandra Bayu Kurniawan, Anesa, Istiyati, Sularmi dan Hadiyah (2021)

First publication right:

Journal Syntax Literate

This article is licensed under:

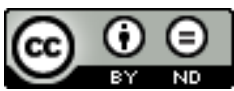

